\title{
APLICAÇÃO DE METODOLOGIAS PARTICIPATIVAS EM TERRITÓRIO PARA DESENVOLVIMENTO DE APLICATIVO MÓVEL: UM ESTUDO PILOTO
}

\author{
Kareen Andrade Litaiff \\ Universidade de Brasília \\ kareenlitaiff@gmail.com \\ Andrea Castello Branco Judice, Dra \\ Universidade de Brasília \\ acbjudice@gmail.com
}

Resumo: neste pôster são apresentadas a aplicação e a implicação de abordagens participativas e empáticas na região de Itapoã-DF. O objetivo é aplicar metodologias participativas voltadas para desenvolvimento de projetos de fortalecimento do empreendedorismo por meio da economia criativa a fim de desenvolver um aplicativo móvel. Os objetivos específicos do projeto são analisar a comunidade, a linguagem utilizada e compreender as reais necessidades de seus usuários. Auxiliar na solidificação de sua identidade cultural dentre e fora da comunidade. Entender suas expectativas e necessidades. Primeiramente foram desenvolvidas oficinas com os líderes comunitários para identificação de temas a serem trabalhados. Com as devidas observações e análise é possível apurar a maneira mais eficiente de transmitir tais metodologias de projeto, como adaptação em diferentes mídias e formatos, para que seus usuários possam aplicá-las em futuros empreendimentos. As metodologias têm foco no design participativo escandinavo e no design empático finlandês. A escolha de desenvolver um aplicativo como produto final se deu após análise das entrevistas e observações etnográficas em contexto. Como resultado, este projeto permitirá aos pesquisadores observar e entender quais métodos farão parte do aplicativo móvel que será usado como uma ferramenta toolkit em projetos focados na Economia Criativa.

Palavras-chave: Metodologias Participativas, Integração, Comunidade, Aplicativo móvel 